\title{
New Directions in British Historiography: the Emergence of Cultural History?
}

Une histoire culturelle a-t-elle emergé?

John K. Walton

\section{CpenEdition}

1 Journals

\section{Electronic version}

URL: http://journals.openedition.org/rfcb/5972

DOI: $10.4000 /$ rfcb.5972

ISSN: 2429-4373

\section{Publisher}

CRECIB - Centre de recherche et d'études en civilisation britannique

\section{Printed version}

Date of publication: 1 April 2008

ISSN: 0248-9015

\section{Electronic reference}

John K. Walton, « New Directions in British Historiography: the Emergence of Cultural History? », Revue Française de Civilisation Britannique [Online], XIV-4 | 2008, Online since 01 April 2008, connection on 20 September 2020. URL : http://journals.openedition.org/rfcb/5972 ; DOI : https://doi.org/10.4000/rfcb. 5972

This text was automatically generated on 20 September 2020 .

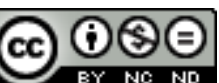

Revue française de civilisation britannique est mis à disposition selon les termes de la licence Creative Commons Attribution - Pas d'Utilisation Commerciale - Pas de Modification 4.0 International. 


\title{
New Directions in British
} Historiography: the Emergence of Cultural History?

\author{
Une histoire culturelle a-t-elle emergé?
}

John K. Walton

1 At the beginning of the twenty-first century the Social History Society of the United Kingdom, impelled by the accession of a rising generation of scholars to its management committee, sought new directions, inspirations and ambitions. As part of this necessary - and apparently successful - renovation process it decided to establish a new journal, to reflect and express the members' evolving interests and priorities. But what should such a journal be called? There were already two well-established journals bearing the title Social History; ${ }^{1}$ and besides, the majority of the committee wanted to be seen to embrace new developments in the discipline, in the direction of something that might be summarised as a 'cultural turn', without losing the original identity of the Society or alienating too many of its members. The result was Cultural and Social History, which has just completed its fourth year of publication; and the process described above, with all its indications of restiveness, uncertainty and compromise, might stand as an allegory or metaphor for the recent development and current state of 'cultural history' in the United Kingdom.

2 The new journal began with controversy and ambiguity over the nature and validity of the concept and practice of 'cultural history'. The inaugural editorial began with the clear statements that culture and society were 'mutually constituted and inextricably linked' and that culture was a product of social practices. Lord Briggs added his view that many of the pioneer British social historians now saw themselves principally as cultural historians, and identified himself with this position. Harold Perkin, author of The Origins of Modern English Society, who took immense pride in being the first Assistant Lecturer, and later the first Professor, of Social History (so described), offered a definition of culture as the anthropology of everyday life and as involving 'activities that constitute the ends of life which the economic and political means serve', such as 
arts and sciences, music and literature, sport, leisure and religion. ${ }^{2}$ The editors announced their intention to encourage debate on the nature, content and methodologies of cultural and social history, beginning with a contribution by Peter Mandler (author of - among other things - a substantial history of the English stately home and its visitors), which cast doubt on aspects of current practices of textual analysis (especially via the credentials of chosen texts to be representative), attacked the privileging of some texts and discourses over others without careful examination of context and influence, and deprecated the ways in which meaning was constructed in some cultural history projects, while affirming the desirability of re-engaging in dialogue with the 'social sciences'. ${ }^{3}$ This in turn generated some critical responses, in which disappointment shaded off into anger. Colin Jones, a British-based historian of the French Revolution, ${ }^{4}$ was particularly acerbic, especially towards Mandler's dismissal of theoretically-inclined cultural historians as immature and undisciplined, and his setting up of 'straw' historians and texts for methodological condemnation. Carla Hesse, a historian of gender and cultural politics revolutionary Paris based in the United States, ${ }^{5}$ emphasised her perception that Mandler was focusing his critical attention on a minority, arguing that few practitioners of 'cultural history' would quarrel with John Tosh's definition of best practice as 'the dialectic between meaning and experience'. Carol Watts, an American literary historian interested in Lawrence Sterne and representations of eighteenth-century empire, ${ }^{6}$ going beyond Mandler's overt agenda in his article, included the 'history of everyday life' and 'history from below' as examples of the 'cultural turn', tracing its roots back beyond current fashions in textual analysis to Annales and other interdisciplinary influences from earlier decades, and taking an ecumenical view of the range of approaches and themes that could be included under the 'cultural history' heading. As befitted an expert on Sterne's Tristram Shandy, she was also worried by the implication that Mandler did not think it desirable for historians to have fun. ${ }^{7}$ These exchanges immediately drew attention to the scope for dispute and debate about what constituted cultural history and the 'cultural turn', what other developments it should be associated with, and how novel its concerns actually were. Taking these issues into account creates considerable difficulties in attempting to assess the extent and significance of a 'cultural turn' in British historical practice since, perhaps, the late twentieth century.

3 It is obvious that some contextual comment is necessary; and tracing the roots of a distinctive British tradition of 'cultural history', which was not much in evidence in the Cultural and Social History debates, complicates the background considerably. The question of what constituted 'social history' had long been a vexed issue in itself, with various philosophies and approaches on offer, some entailing apparent mutual incompatibilities. As Miles Taylor had pointed out a few years previously, social history was itself the direct descendant of earlier strands in British historiography, from the pioneering labour historians J.L. and Barbara Hammond, ${ }^{8}$ the original broad-brush 'social historian' G.M. Trevelyan, ${ }^{9}$ and Sir Lewis Namier, ${ }^{10}$ the analyst of eighteenthcentury political connections and interest-groups, onwards, and its ancestries could be represented across a spectrum from the conservative to the socialist, with little commitment to any articulated body of theory ${ }^{11}$ In many respects social history within academe grew out of and alongside economic history, and many university departments yoked the two together as they expanded over the post-war generation, assimilating them in the process to a British academic culture that remained suspicious of 'theory', especially when it was imported from beyond the islands. The key 
exceptions were neo-classical economics (which became the 'common sense' of most economic history) and the distinctive brand of Marxism from which (for example) the distinguished journal Past and Present was born in 1952, which struggled during the 1950s and early 1960s against Cold War prejudices which at times almost amounted to academic McCarthyism. ${ }^{12}$ Alongside the emergence of social and economic history, though without dedicated departments of its own, came the rise of labour history, whose close relationship with social history helped to associate the latter with the history of the working class, despite the efforts of Perkin and others to promote a holistic approach across society. ${ }^{13}$ E.P. Thompson's defining text The Making of the English Working Class, rooted in the relationships between economic circumstances, labour relations, popular politics and popular culture in the industrialising West Riding of Yorkshire, was first published in $1963 .{ }^{14}$ Three years later the History Workshop movement began at Ruskin College, Oxford, with an early commitment to 'people's history', as befitted the college's identity as a centre for centre for trade unionist education and working-class mature students, and following the inspiration of Raphael Samuel, another key figure in the origins of the 'popular' incarnation of cultural history. ${ }^{15}$ History Workshop became identified in its early years with the recovery, celebration and documentation of past working lives, a distinctive socialist version of 'history from the bottom up' which sought to re-create past cultures through what Carolyn Steedman later described as 'molecular vision and micro-history'; and it was in this spirit that History Workshop Journal was founded, to pursue 'people's history and socialist theory' (in that order, at first), with the first issue appearing in $1976 .{ }^{16}$

4 Meanwhile, groundwork of a different sort was being laid by Raymond Williams and Richard Hoggart, who, like E.P. Thompson, began their academic careers in adult education. In their case this was combined with working-class origins, though in sharply contrasting settings. Williams, author of Culture and Society, The Long Revolution and Keywords, saw culture as 'a whole way of life... common meanings, the product of a whole people, and offered individual meanings', and his interpretations of long-term cultural change gave him a reputation as cultural historian as well as literary critic; while Hoggart's The Uses of Literacy delineated the working-class culture of his native Hunslet (Leeds) in ways that might also be taken to validate popular history, although the trajectory of his Centre for Contemporary Cultural Studies at Birmingham University was to move in other directions. Hoggart himself (who has never been a Marxist and was never identified with postmodernism in any academic sense) has been marginalised from the mainstream of cultural studies and cultural history, although recent reappraisals as a 'public intellectual', a cultural critic of enduring relevance, and (significantly for present purposes) a practitioner of a 'discourse of empathy', a pioneer of 'speaking the self' as a form of historical practice, and a provider of 'neglected resources' for historians, suggest an impending recognition of the enduring value of his ideas. ${ }^{17}$ Such comments bring Hoggart's approach to history, through the reflexive retrospective examination of personal experience, close to another emergent strand of British cultural history from the late 1960s, associated with second-wave feminism, Sheila Rowbotham (and her autobiographical writings), ${ }^{18}$ and a 'politics rooted in historical awareness', together with 'pioneering uses of autobiography and oral history' ${ }^{19}$ Nor should we forget the historical dimension of Mass-Observation, that distinctive mid-century moment and movement in the anthropology of the popular: not only did the Birmingham Centre for Contemporary Cultural Studies defend it against derisive 'scientific' Sociology in the 1970s, and not only did its archives provide 
an increasingly attractive resource for practitioners of cultural and social history from (especially) the 1990s onwards, but its founder, Tom Harrisson, also produced a history of his own, his picaresque examination of Blackpool on the eve of the Second World War, although it was not published (and then only in edited form) until 1990. ${ }^{20}$

These initiatives, taken together and combined with an 'empirical' concern, evident in much History Workshop endeavour, to recover popular pasts through the accumulation of detail (sometimes anticipating the confection of what came to be theorised as 'microhistories'), produced what by the early 1980s could be regarded as an emergent British approach to the social history of popular culture, itself a form of 'cultural history' which operated alongside more traditional ways of writing about 'high culture'. Already in the mid to late 1970s, however, responses from strands in Marxist and then post-Marxist theory began to generate conflict over how these histories should be researched and written. ${ }^{21}$ At the Centre for Contemporary Cultural Studies Richard Johnson, who had taken over the directorship from Hoggart, espoused a 'structuralist' approach to cultural analysis which was identified with Louis Althusser, and which challenged the relevance of the detailed recovery of past lives and circumstances which had been important to early History Workshop practice. Edward Thompson attacked this position fiercely in his The Poverty of Theory (1978), and the stage was set (literally) for a set-piece confrontation at the 1979 History Workshop, where debate went forward in a deconsecrated chapel which was literally packed to the rafters, with participants dangling from every conceivable vantage point. This was, perhaps, the point at which suspicion of both 'Continental' theory and linguistic analysis confirmed its entry into the core of much emergent British social and cultural history, which made the development that followed during the 1980 s and 1990s all the more contentious. The History Workshop meeting of 1979 carried the label 'People's History and Socialist Theory', and the thick folder of 'position papers' issued to participants, cyclostyled in an endless variety of typefaces, formats and layouts, and with various key pages and contributions missing, still conjures up the combative earnestness of those times, when the dominant themes were labour history, socialist history, ways of doing socialist local history, and the radical history of political economy. ${ }^{22}$

6 At that point Margaret Thatcher had been in power for nearly six months, and in retrospect it is easy to identify this gathering with the end of an era, or at least with the beginning of a period of transition. No individual trajectory can tell a whole story, but one in particular seems significant. At the 1979 History Workshop, Gareth Stedman Jones contributed a paper on 'Utopian Socialism Reconsidered.' He was already well known as the author of Outcast London, a seminal, beautifully-researched and argued examination of the economic circumstances and survival strategies of (especially) casual and seasonal workers in London's late Victorian East End, and of a long and thorough article in Journal of Social History on the alleged relationship between workingclass politics and culture in Victorian London, which argued that the latter became defensive, inward-looking and prone to voting Conservative. ${ }^{23}$ In 1983 , however, he became a pioneer of the 'linguistic turn' in British historiography, publishing a very substantial - and controversial - argument to the effect that the only viable route to understanding Chartism, or by implication any other political or cultural phenomenon, was through the linguistic analysis of selected texts, thereby steering the course of historical interpretation away from attempts to reconstruct past relationships and experiences and towards the view that nothing could be apprehended beyond the text. ${ }^{24}$ As the London Marxist Keith Flett put it in 2002, this was 'a staging post on his long 
journey from being one of the sharpest social historians of the 1960s and 1970s, to someone who is now focused on the history of political ideas and disillusioned with the left. ${ }^{25}$ The sense of betrayal experienced by those who remained attached to earlier socio-cultural history projects, whether Marxist, marxisant or sceptical of all overtly articulated theoretical positions, was matched only by the enthusiasm of those who followed a similar route.

But it was not until the early 1990s that the 'linguistic turn' and postmodernism really gathered momentum in British history, importing developments in continental Europe and the United States. One of its symptomatic starting points was in the pages of Social History, where historians of labour and industrial relations in the Industrial Revolution began to debate language and discourse in 1986, while the American anthropologist Thomas C. Patterson urged historians to think about the implications for their discipline of post-structuralism and postmodernism more generally in $1989 .{ }^{26}$ It was impelled by Keith Jenkins's provocative Rethinking History, first published in 1991, which later gave its name to a journal edited by Alun Munslow, another promoter of the application of European philosophies to British historical practice; and in the specific context of social and cultural history the work of Patrick Joyce was particularly visible. Indeed, at times it began to resemble a personal crusade, as Joyce took part in a series of debates on history and theory, in Past and Present as well as Social History, and kept returning to the fray in response to each critical reaction. The debate over language, discourse and post-modernism in social - and, in practice, 'cultural' - history began in response to Stedman Jones, with an early critique from a historical materialist perspective by Neville Kirk in International Review of Social History in 1987, ${ }^{27}$ and raged at its most tempestuous in Social History between 1992 and 1996, with important contributions from Kirk, James Vernon, Geoff Eley and Keith Nield (one of the editors of Social History). It reached a melodramatic climax in 1995, with Joyce's apocalyptically titled 'The end of social history?' and died away after exchanges between Joyce, Eley and Nield. ${ }^{28}$ Joyce's title, of course, alluded to Francis Fukuyama's absurd The End of History, a piece of misplaced post-Cold War triumphalism published in 1992, and this seeming identification, in the aftermath of 'culture wars' over the proper stuff of academic history in the United States and Britain, helped to fuel the controversy, at a point when all the incarnations that might be brought under the capacious umbrella of 'the new cultural history', from 'history from below' to post-modernism, were particularly contentious, threatening to established positions, and themselves threatened by external forces. ${ }^{29}$

8 At about this point the sound and fury began to fade from conflict within the British historical profession over the nature of the discipline, at least as it affected perceptions of social and cultural history. The History Workshop tradition of regular gatherings, at Ruskin College and elsewhere, sputtered and died, as Ruskin encountered a series of problems of its own. History Workshop Journal became a mainstream, though still distinctive, academic journal, losing its connections with people's history and socialist theory alike as it moved across to focus on the literary, the linguistic, the visual, the post-colonial and issues surrounding gender, 'race', ethnicity and identity. Raphael Samuel, before his sadly premature death in 1996, moved across to examining the cultural politics of national identity and the creation of democratic versions of history through popular consumerism, family history and the construction and celebration of 'heritage'. ${ }^{30}$ Conceptions of class faded from view as other kinds of cultural identity were brought to the foreground. Social History announced on its website that, 'The 
editors wish to see a move away from radical divisions drawn between the social and the cultural', but it was still unclear where lines were to be drawn between the categories, if at all. Arguments about the nature and merits of the 'cultural turn' persisted elsewhere: they reached the pages of the Journal of Transport History in the early twenty-first century, for example. ${ }^{31}$ The most important point, however, is that the memory of these recent conflicts, together with the persisting antagonisms they fuelled within significant areas of British history, sustains the problematic nature of providing a working definition of 'cultural history', especially in relation to social history, leaving aside the enduring perception among historians of high politics and elite culture that nothing else really matters or has legitimacy. ${ }^{32}$ Hence the need for the historical context that I have sought to provide in the foregoing paragraphs.

The status of cultural history, of whatever kind, remains uncertain in Britain, and especially among British historians working on British themes. It is perhaps significant that it still difficult to find Professors of Cultural History, so labelled, in Britain, especially pursuing British research interests within Departments of History. At the University of Manchester, for example, Bertrand Taithe holds this title; but his colleague Patrick Joyce, who features so prominently as a pioneer of British postmodernism and the 'linguistic' if not the 'cultural turn', is Professor of Modern History. Jeffrey Richards, at Lancaster University, has long held the title 'Professor of Cultural History', but his proudly idiosyncratic approach to histories of cinema, the stage, music and English or British identity leaves him outside any attempt at classification. At Dundee Callum Brown, an original and combative historian but not notable as an evangelical exponent of theory-driven history, is Professor of Religious and Cultural History, but neither Alun Munslow, founding editor of Rethinking History, nor his colleague Keith Jenkins, author of the book of the same title, have the word 'cultural' in their professorial titles. It would be interesting to explore this question of descriptors and their significance in greater depth, but initial impressions are that 'social' remains much more popular than 'cultural' in this respect, although this may reflect in part the different priorities of an 'established' and a 'rising' generation.

Publications overtly announcing a focus on British cultural history are likewise in short supply. A survey of entries containing the words 'British cultural history' in the British Library on-line catalogue finds 244 in all; but hardly any are attributed to professional historians writing on British themes in British universities, although this crudely literal approach failed to pick up a significant number of potential contenders. The overwhelming majority deal with 'culture' in an artistic sense, broadly defined: art, photography, cinema, novels and travel writing. Distinctive thematic approaches took the form of gender, 'race' and identity, especially national and colonial identity. Of the eight books or theses on British themes by British authors or editors to appear under this heading, two dealt with aspects of the First and Second World Wars; one with 'nature' and the imagination; one with the cultural diversity of the emergent English middle classes; one with cultural identities in (mainly) eighteenth-century Britain and Ireland; one with the institutional culture (among other themes) of Victorian lunatic asylums; one with British scientific culture; and one with the 'social and cultural history' of the British Communist Party. This is hardly a 'scientific' survey, but it suggests that any attempt to quantify and classify the output of British practitioners of anything that might be labelled 'cultural history' is akin to chasing mist across marshland, not least because nobody can agree about the nature of the quarry. There is nothing to anchor the phrase consistently in any particular category, or cluster, of 
historical practices. We already knew that culture is as elastic and polymorphous a keyword as class; and Michel Foucault could, of course, have predicted this outcome.

11 The lack of certainty or consensus about what might constitute 'cultural history' is also apparent in course descriptions. For example, the University of Manchester lays claim to being 'a major centre of the new cultural histories, of the new social history, gender history, the new histories of art and science, and so on.' But the promotional material for its MA in Cultural History tells potential applicants, "While "cultural history" denotes an inter-disciplinary approach, the transformation of the discipline of History itself is the focus of the core course "History and Postmodernism"', seeming to suggest an assumed elective affinity between cultural history and postmodernism. We are told that cultural history entails interdisciplinarity, with a promise of intellectual interaction with 'sociology, literary studies, politics and so on'. This vagueness (including the reiterated 'and so on') is a further indication of the nebulous nature of 'cultural history' itself, which is perhaps appropriate in the light of the programme's emphasis on the problematic nature of classification and identity in historical studies. ${ }^{33}$ The postgraduate programme in Cultural and Social History at the University of Essex likewise offers few and limited clues to the external enquirer: it promises a "critical assessment of what makes cultural history distinctive and, in particular, the extent to which it can be considered distinct from social history', with emphasis on the challenges posed by the 'cultural turn' to older assumptions and approaches. The module on 'Approaches to cultural and social history' (HR924-G-SP) identifies 'subjectivity, identities, discourses' among the key concepts in cultural history, and among the 'debates and themes' are 'childhood, the public and the private, sex, the psyche, memory'. But to discover why these concepts, debates and themes were thus highlighted, rather than a spectrum of other possibilities, one would have to experience the module. ${ }^{34}$

12 At undergraduate level, the extent to which 'cultural history' has permeated the undergraduate study schemes of History departments and degree programmes in higher education should not be exaggerated, as the work of Simon Gunn and Stuart Rawnsley has demonstrated. Their research agenda was not directed explicitly at 'cultural history', but their survey of the taught modules in History offered by British universities, supplemented by interviews with a small selection of academic staff, finds an enduring conservatism in the form of suspicion among senior staff of new-fangled foreign ideas, unwillingness to impose sustained investigation or use of theoretical perspectives in imparting the culture of the discipline, and a preference for the teaching of 'sources and methods' in a 'commonsense' manner, alongside an overview of trends in 'historiography', rather than interdisciplinary approaches to 'history and theory'. Such concerns tended to be confined to the modules that were dedicated to them, making little impact on content-led work in other parts of the syllabus, which is, however, where encounters with aspects of 'cultural history, on the generous definition offered by Carol Watts, were perhaps more likely to take place. ${ }^{35}$

13 Another recent survey (British in authorship but international in scope) of the teaching of History in higher education, by Timmins, Vernon and Kinealy, complicates matters further by introducing the concepts of Old and New History, which seem to be divided on the basis of politics, diplomacy and policy making versus culture, representations and textual analysis. It proceeds by placing E.P. Thompson at the centre of the development of a cultural history defined essentially by social inclusion and an 
interdisciplinary spirit, and by eliding this into the subsequent emergence of postmodernism and the 'linguistic turn', emphasizing the dangerously relativistic implications (especially for History as hitherto understood) of regarding all the world as a text. ${ }^{36}$ But the authors share a widespread view that the tide of postmodernism, and the associated high water mark of this incarnation of the 'new cultural history', has been reached, and that these turbid and perilous waters have been ebbing since the turn of the millennium. ${ }^{37}$ We shall see that this perception is probably too simple, and that changes in the teaching practices of historians, like the more accessible innovations in their research and writing, have been more subtle than the examination of advertised module titles and summarised content might suggest.

Confusion also becomes apparent when historians try to articulate their vision of the relationship between cultural and social history, especially within the revealingly compressed confines of an article abstract aimed at an audience extending beyond the specialist and even the academic, as in the case of the on-line journal History Compass. J. Carter Wood, summarising his survey article on 'criminal violence in modern Britain', presents an explicit dichotomy between social history as a discipline based on quantification and cultural history as entailing the use of qualitative approaches to understanding narrative and discourse ${ }^{38}$ In the same journal, P.K. Monod identifies cultural history with the developing interest in consumption and consumerism in eighteenth-century Britain, in association with a growing concern with gender, national and racial identities, and sees this as part of a shift away from an older social history which focused its attention on the 'labouring classes'. Monod professes eagerness to see these imagined divisions redressed and the boundaries between cultural and social history, as he identifies them, dissolved. ${ }^{39}$ In practice, however, it is remarkably difficult to map these dichotomies (social history is quantitative, cultural history qualitative; social history is about class, especially the working class, and production, while cultural history is about consumption, identities and gender), or any others, on to what 'cultural' and 'social' historians actually do. E.P. Thompson wrote about class, using qualitative sources and approaches ('methodologies' does not seem appropriate here) and coining an oft-quoted definition of his own which emphasised process and human agency. He was accused by some of being altogether too 'cultural' in his agenda to qualify as a 'proper' scientific Marxist, while also attracting critical comment for his inattention to gender, which was perhaps encapsulated by his reference to 'men' in that same definition (first published in 1963). ${ }^{40}$

But it is time to explore these imagined distinctions further. It is possible to construct a series of questions which might help us to investigate the identity or identities of cultural history as an imagined new set of theorised approaches and practices (as opposed to histories of aspects of 'high' or 'popular' culture, such as opera or musichall, although this basic usage of the term, signposting subject matter rather than philosophy or methodology, can easily cloud the issue). Here is a selection of tempting binary oppositions, which invite careful deconstruction. Is cultural history to postmodernity what social history is to modernity? Is cultural history about consumption where social history is about production? Is cultural history about gender and identity where social history is about class? Does cultural history celebrate subjectivities while social history pursues objectivity? Moving beyond the binaries: is cultural history interdisciplinary in new ways, reaching out beyond the established relationships between social history and sociology, anthropology or economics, its long-imagined evil twin, and engaging rather with literature, art history, media and cultural studies, 
and gender studies? Is cultural history eclectic and promiscuous in its borrowings? Would this be a good thing? Is cultural history specifically to be identified with new subject areas? If so which ones?

16 In a brief overview of this sort these are questions to be raised rather than answered. After all, none of these questions can be dealt with by a simple 'yes' or 'no', and each would merit an essay in its own right. What remains clear is that trying to carve out a clear, uncontentious identity for something called 'cultural history' in the British context is an impossible task. We could try to draw a tentative line between an indigenous tradition of British cultural history that is social, anthropological and working-class in its approach and subject matter, and an imported cultural history that is linguistic, textual and concerned more overtly with subjectivity, reflexivity and the negotiation of identities; but even this would over-simplify, although we might note that none of the critics of Peter Mandler with whom this essay began were historians of Britain who were also based in that country. Their frame of reference, in terms of cited theoretical influences, was overwhelmingly North American and European in scope. Perhaps I should emphasize that this is not intended as a criticism: quite the reverse. But it does draw attention to the many mansions within the imagined house of 'cultural history', and the permeability of its external walls.

17 It remains abundantly clear that, although the polemics around conflicting versions of cultural and social history have subsided, the cumulative influence of these broad approaches to historical research and writing has continued to permeate the discipline. Four years ago Keith Jenkins expressed the view that the ideas promoted in Rethinking History had been accorded only token acceptance, as providing useful polemical material to stimulate discussion on courses dedicated to historiography, sources and methods, and had not filtered through into mainstream historical practice. ${ }^{41}$ The journal of the same name has continued to extend the frontiers of history, with recent special issues on historical fiction and historical re-enactment. ${ }^{42}$ But what has happened more generally, going beyond the post-modern aspects of the 'cultural turn', has been quietly dramatic. To adapt a phrase of E.P. Thompson's about the workingclass response to the decline of Chartism, the broad agenda associated with 'cultural history' has mined the historical profession almost from end to end. We now have cultural histories of politics, diplomacy, even (via management culture and cultures of consumerism) of economics and economic institutions. ${ }^{43}$ We have a growing groundswell of expectation about the imagined rebuilding of bridges between cultural and social history. ${ }^{44}$ We have abundant evidence, outside the former enclosures of the specialised histories of art or cinema and television, of 'mainstream' historians' growing interest in the use of visual sources, and moving images, alongside written texts and documents, of attempts to tackle histories of sounds and smells, and even to re-create past performances and pleasures in scholarly ways, as in the case of Vanessa Toulmin's re-creation of past popular entertainment by mounting a programme of live shows on the Blackpool stage, using funding from the Arts and Humanities Research Council. ${ }^{45}$ Moreover, an examination of courses offered, and of staff research interests, across most British universities (and not just the former polytechnics, as Gunn and Rawnsley implicitly demonstrate), would demonstrate a strong 'turn to culture' in the agendas displayed. This has been a quiet, almost a silent, cultural revolution, over the past twenty years; and it awaits its chronicler. This article does no more than begin to lay the groundwork for further, more sophisticated analysis. 


\section{NOTES}

1. The Social History that is edited from the University of Hull now describes itself on its website, but not its masthead, as a journal of social and cultural history (my italics).

2. Editorial, Cultural and Social History 1 (2004), pp. 1-5; H.J. PERKIN, The Origins of Modern English Society, London: Routledge, 1969.

3. P. MANDLER, 'The problem with cultural history', Cultural and Social History 1 (2004), pp. 94-117.

4. See, for example, Colin JONES, The Great Nation: France from Louis XV to Napoleon, London: Allen Lane, 2002.

5. Carla HESSE, Publishing and Cultural Politics in Revolutionary Paris, Berkeley, CA: University of California Press, 1991; The Other Enlightenment: how French Women became Modern, Princeton University Press, 2001.

6. Carol WATTS, The Cultural Work of Empire, Edinburgh University Press, 2002.

7. C. HESSE, 'The new empiricism'; Colin JONES, 'Peter Mandler's "Problem with social history"'; and C. WATTS, 'Thinking about the X factor', all in Cultural and Social History 1 (2004), pp. 201-22.

8. Stewart A. WEAVER, The Hammonds: a Marriage in History, Stanford University Press, 1997.

9. David CANNADINE, G.M. Trevelyan: a Life in History, London: HarperCollins, 1992.

10. Linda COLLEY, Lewis Namier, London: Weidenfeld and Nicolson, 1989.

11. Miles TAYLOR, 'The beginnings of modern British social history', History Workshop Journal 43 (1997), a title that conjures up Harold Perkin's path-breaking foundation text The origins of modern English society, London: Routledge, 1969.

12. Harvey J. KAYE, The British Marxist Historians, Cambridge: Polity, 1984.

13. The (English) Society for the Study of Labour History was founded in 1960.

14. E.P. THOMPSON, The Making of the English Working Class (Harmondsworth: Penguin, 1963); Bryan D. PALMER, The Making of E.P. Thompson, Toronto: New Hogtown Press, 1981.

15. Keith FLETT, 'Artisan of History', Socialist Review 204 (January 1997); G. ANDREWS, H. KEANE \& J. THOMPSON (eds.), Ruskin College: Contesting Knowledge, Dissenting Politics, London: Lawrence and Wishart, 1999.

16. Carolyn STEEDMAN, 'Raphael Samuel 1934-1996', Radical Philosophy March/April 1997.

17. Richard HOGGART, The Uses of Literacy, Harmondsworth: Penguin, 1957; Stephen WOODHAMS, History in the Making: Raymond Williams, Edward Thompson and radical intellectuals 1936-1956, London: Merlin, 2001; Denis DWORKIN, Cultural Marxism in Postwar Britain, Durham, NC: Duke University Press, 1997; Jim McGUIGAN, 'Richard Hoggart: public intellectual', International Journal of Cultural Policy 12 (2006), pp. 199-208; Sue OWEN, 'The Abuse of Literacy and the feeling heart: the trials of Richard Hoggart', Cambridge Quarterly 34 (2005), pp. 199-208; Melissa GREGG, 'A neglected history: Richard Hoggart's discourse of empathy', Rethinking History 7 (2003), pp. 285-306. Gregg's abstract provides a memorable characterisation of cultural studies as a 'relentlessly naval-gazing (sic, perhaps?) discipline'.

18. Sheila ROWBOTHAM is best known for her Hidden from History, London: Pluto, 1973, a pioneering work in women's history, and for Promise of a Dream: Remembering the Sixties, London: Allen Lane, 2000.

19. Eve SETCH, 'Personal History', History Workshop Journal 53 (2002), pp. 269-73.

20. Gary CROSS (ed.), Worktowners at Blackpool, London: Routledge, 1990.

21. Graeme TURNER, British Cultural Studies: an Introduction, $3^{\text {rd }}$ edition, London: Routledge, 2002, especially pp. 57-8, fills in some of the gaps in the story.

22. E.P. THOMPSON, The Poverty of Theory, London: Merlin Press, 1978; Denis DWORKIN, Cultural Marxism; Ruskin History Workshop 13: Position Papers, Ruskin College, Walton St., Oxford, Nov. $30^{\text {th }}-$ Dec. $2^{\text {nd }} 1979$, copy in the author's possession. 
23. G. STEDMAN JONES, Outcast London, Oxford: Clarendon, 1971; idem., 'Working-class culture and working-class politics in Victorian London', Journal of Social History 9 (1974), pp. 460-508. For a critique of this article, M. BRODIE, The Politics of the Poor: the East End of London 1885-1914, Oxford: Clarendon, 2004.

24. G. STEDMAN JONES, 'Rethinking Chartism', in Languages of Class (Cambridge University Press, 1983), pp. 90-178.

25. Keith FLETT, Review of Stedman Jones's Introduction to the Penguin edition of the Communist Manifesto, London Socialist Historians' Newsletter 16 (2002).

26. John SMAIL, 'New languages for labour and capital', Social History 12 (1987), pp. 49-72; A. RANDALL, 'New languages for old?', Social History 15 (1990), pp. 195-216; T.C. PATTERSON, 'Poststructuralism, post-modernism: implications for historians', Social History 14 (1989), pp. 83-8; and see also R. GRAY, 'The deconstructing of the English working class', Social History 11 (1986), pp. 363-74. .

27. N. KIRK, 'In defence of class', International Review of Social History 32 (1987), pp. 2-47.

28. The significant contributions to debate were D. MAYFIELD \& S. THORNE, 'Social history and its discontents: Gareth Stedman Jones and the politics of language', Social History 17 (1992), pp. 165-84; Jon LAWRENCE \& Miles TAYLOR, reply to Mayfield and Thorne, Social History 18 (1993), pp. 17-30; reply by MAYFIELD \& THORNE, Social History 18 (1993), pp. 219-34; P. JOYCE, 'The imaginary discontents of social history', Social History 18 (1993), pp. 81-6; J. VERNON, 'Who's afraid of the "linguistic turn"?', Social History 19 (1994), pp. 81-98; N. KIRK, 'History, language, ideas and postmodernism', Social History 19 (1994), pp. 221-40; JOYCE, 'The end of social history?', Social History 20 (1995), pp. 73-92; G. ELEY \& K. NIELD, 'Starting over', Social History 20 (1995), pp. 355-64; JOYCE, reply to Eley and Nield, Social History 21 (1996), pp. 96-8.

29. F. FUKUYAMA, The End of History, New York: Free Press, 1992; Journal of Social History 29 (1995), special supplement; Richard EVANS, In Defence of History, London: Granta, 1997; Evans's responses to his critics, http://www.history.ac.uk/hr/Focus/Whatishistory/evans.html accessed 23 January 2008.

30. R. SAMUEL, Theatres of Memory I: Past and Present in Contemporary Culture, London: Verso, 1994; II: Island Stories, ed. Alison LIGHT with Sally ALEXANDER \& Gareth STEDMAN JONES, London: Verso, 1998. A posthumous, reflexive cultural history, The Lost World of British Communism, London: Verso, 2006, has recently appeared.

31. J.K. WALTON, 'Transport, travel, tourism and mobility: a cultural turn?', Journal of Transport History, third series, 27 (2006), pp. 129-34, referring back to earlier discussions.

32. http://www.history.ac.uk/hr/Focus/Whatishistory/evans.html accessed 23 January 2008, for Evans's comments on attacks on popular and cultural history; J.K. WALTON, 'The lion and the newt: a British view of American conservatives' fear of social history', Journal of Social History 29 (1995), special supplement, pp. 73-84.

33. www.manchester.ac.uk/postgraduate/taughtdegrees/courses/atoz/course/? code $=011338 \&$ pg=all accessed 22 January 2008 .

34. http://www.essex.ac.uk/intro/pg/scheme_profle.asp?myprog=MA++VL131207 accessed 23 January 2008.

35. Simon GUNN \& Stuart RAWNSLEY, 'Practising reflexivity: the place of theory in University history', Rethinking History 10 (2006), pp. 369-90.

36. Geoff TIMMINS, Keith VERNON \& Christine KINEALY, Teaching and Learning History London: Sage, 2005, pp. 14-22; see also J.G. TIMMINS, 'The future of learning and teaching in social history', Journal of Social History 39 (2006), pp. 829-42.

37. G. TIMMINS, K. VERNON \& C. KINEALY, Teaching and Learning History, op. cit., p. 21.

38. J. CARTER WOOD, 'Criminal violence in modern Britain', History Compass 4 (2006), abstract.

39. P.K. MONOD, 'Are you getting enough culture? Moving from social to cultural history in eighteenth-century Britain', History Compass 5 (2007), abstract. 
40. Gerard McCANN, Theory and History: the Political Thought of E.P. Thompson, Aldershot: Ashgate, 1997; Anna CLARK, The Struggle for the Breeches, Berkeley: University of California Press, 1995.

41. http://www.galilean-library.org/jenkins.html accessed 22 January 2008.

42. Rethinking History 9 (2-3), 2005, special issue on history, fiction and historical fiction; Rethinking History 11 (3), 2007, special issue on historical re-enactment.

43. Examples might include M.J. DAUNTON \& M. HILTON (eds.), The Politics of Consumption, Oxford: Berg, 2002; James TAYLOR, Creating Capitalism: Joint-Stock Enterprise in British Politics and Culture, 1800-1870, Woodbridge: Boydell, 2006; Maxine BERG, Luxury and Pleasure in Eighteenth-Century Britain, Oxford University Press, 2005.

44. Peter BORSAY, 'New approaches to social history: myth, memory and place', Journal of Social History 39 (2006), pp. 867-89.

45. Emily COCKAYNE, Hubbub: filth, noise and stench in England 1600-1770, New Haven: Yale University Press, 2007; Special issue, 'Sounding the town', Urban History 29, May 2002; Vanessa TOULMIN, 'Admission all classes', entertainment programme supported by the National Fairground Archive, University of Sheffield, with Blackpool Council and the Arts and Humanities Research Council, Blackpool, 2007-8: www.admissionallparts.com accessed 25 January 2008.

\section{ABSTRACTS}

The idea of a 'cultural turn' in the philosophy and subject matter of British academic historians is much discussed but difficult to substantiate. This article investigates the emergence of 'cultural history' as a category used by and about British historians of Britain, establishing the context of changes in the agenda of 'social history', the 'linguistic turn' of the 1980s and 1990s, and changing relationships between 'the social' and 'the cultural'. It examines teaching and postgraduate research as well as academic outputs, concluding that the impact of cultural history, in various guises, can best be described as additive rather than substitutive.

L'idée d'un «tournant culturel » dans la philosophie et dans les objets d'étude des historiens britanniques est largement discutée, mais il est difficile de définir ce «tournant». Cet article examine l'émergence de l'« histoire culturelle » comme une catégorie utilisée par et à propos des historiens de la Grande-Bretagne. Il situe le contexte des changements: le programme de l'«histoire sociale», le «tournant linguistique» des années 1980 et 1990 et les relations mouvantes entre «le social» et «le culturel». Il examine non seulement la production universitaire mais aussi les recherches étudiantes et l'enseignement. Il conclut que l'histoire culturelle, sous ses différentes formes, a enrichi l'histoire sociale, plutôt qu'elle ne l'a remplacée.

\section{AUTHOR}

\section{JOHN K. WALTON}

Institute of Northern Studies, Leeds Metropolitan University 